\title{
The Role of Adult Education in Sustaining Cities and Communities in Nigeria: Impact of Fourth Industrial Revolution
}

\author{
-Adedokun M. O.: Department of Adult Education and Community Development, Faculty of Education, Ekiti State \\ University, Nigeria.
}

Adeyemo C. W.: Department of Adult Education and Community Development, Faculty of Education, Ekiti State University, Nigeria.

Agboola B. G.: Department of Adult Education and Community Development, Faculty of Education, Ekiti State University, Nigeria.

Kayode G. M.: Department of Adult Education and Community Development, Faculty of Education, Ekiti State University, Nigeria.

\begin{abstract}
This is an era of technological advancement. New things are springing up daily that needs to be supported with innovative ideas and creativity. Any state that is contented with the status quo is not bound to develop. For rapid development to take place in cities and communities, there is need for a level of disruption. This is the basis and core of the fourth industrial revolution. This paper is based on the fact that every country of the world needs to imbibe the idea of the newest technology with a view to attending to the various challenges facing development especially in Nigerian cities and communities. The challenge of not moving along the newest technological innovations had always led to difficulties in fixing socio-economic problems which eventually inhibit the rate of development in cities and communities and individuals within them. The fourth industrial revolution is not limited to just a group of young people but also adults. Adults should be carried along in the newest technological evolvement through all the laudable programmes of adult education. Technology stimulates creativity which brings about innovation. The fourth industrial revolution which is a combination of earlier technological inventions and revolutions would lead to stimulation of better creativity for sustainable development of cities and communities and of the people. This paper, thus, focused on how integrating technological innovation of the 21 st century into adult education programmes would stimulate creativity in community people thereby leading to creativity, innovations and subsequently sustainability of cities and communities. The authors recommend among others that the Federal Government of Nigeria should focus more on adult education which has immediate relevance to the growth of persons, cities and communities in Nigeria. It is also recommended that technological education should be introduced into all programmes of adult education and efforts should be made to remove every hindrance to technical education from every adult learner and education should be made accessible to all while the curriculum of both the formal and adult education programmes should be replete with elements of the fourth industrial revolution so that none will be left out of the new development agenda.
\end{abstract}

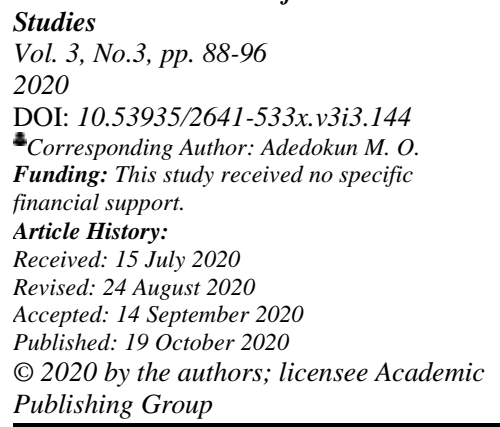




\section{Introduction}

\subsection{Sustainability}

Sustainability has been defined in various ways by various people and authors; however, the most important issue in the word sustainability is the ability to sustain lives, useful objects, and places where we domicile and also making adequate provisions for the future generations. Sustainability is a word that is relevant for every aspect of human endeavour, be it in business, health and sustaining cities and communities. Sustaining our cities and communities is of utmost importance because each person is a member of the community in which he lives. Sustaining such societies means improving upon what has been put in place, which would lead to provision for the needs of adults and the young ones; not neglecting one at the expense of the other (Global Goals, 2018).

Cities in Nigeria are far from what they are expected to be. There is usually an elitist area which is usually surrounded by slums. Though the elitist groups create a centre for themselves; for such centres to be what they are expected to be, the elites must encourage technological knowhow for both the literates and the illiterates in such centres for standards of living to be raised. Technology for the less literate people may not be as advanced as for the literates but should be moderately introduced to them for them to be able to live a life of sustainability.

It is also observed that communities which may be referred to as rural are being deserted on a daily basis especially by the youth who had a kind of dissatisfaction in the rural areas because of lack of adequate technology to make them live up to the standard they would have wanted, this made them to leave for cities in search of better opportunities which unfortunately they could not find. Such youth ended up living in city slums which are worse than the rural communities they left behind. It is important to note that, introducing technology into rural communities, lives would be sustained and youth would not want to leave the rural communities. With technology being introduced there, people would become creative and innovative making them to live above poverty level and with hunger being eradicated (UNICEF Publications, 2017); thus leading to healthy life styles thereby boosting the economy of the nation while at the same time creating enabling atmosphere for generations to come.

In the light of the above, the concepts of education, adult education, innovation technology, and sustainability of cities and communities are examined, in the light of the impact of fourth industrial revolution.

\section{Education}

Most countries of the world associate the term education to the learning of the youth leaving out the adult members of communities and cities, the vulnerable and other marginalized groups in the society (UNESCO., 2019). INCHEON declaration 2030 stated that the right to education is a human right that must be enjoyed by all irrespective of age and location. Education must be inclusive, equitable and of good quality and must be one that promotes lifelong learning for all if sustainability in areas of human endeavours must be achieved. The essence of education is further established that education is a public good, a fundamental human right and a basis for achieving and for guaranteeing the realization of other rights (Education 2030, 2018).

For any type of development to be sustained, education must reach all, ignorance must be wiped off and illiteracy subsided. Making education accessible to all will enable community people to think creatively and be innovative in their ways of doing things thereby reducing poverty and diseases in cities and communities. Education is meant for the empowerment of every citizen weather in cities or rural communities. This type of education is one that is technologically oriented. The era of the fourth industrial revolution is here; a revolution that combines earlier technological revolutions to bring about better access to vital information knowledge sharing and better effective service promotion (Education 2030, 2018).

Education is very much needed to sustain our cities and communities in Nigeria. Talking of sustainable city; it is described as one that places priority on social, economic and environmental development in a bid to allow its inhabitant to live in good conditions and in harmony with their surrounding environment.

Education is meant for the empowerment of everybody in cities or rural communities. Education now goes beyond formal concepts in order to enhance sustainability. Education for all must bring along with it technological innovations for all, irrespective of the level of those involved. People in cities and communities must be armed with necessary information that would make them to be exposed to better creativity and access to vital information and that would lead to knowledge sharing and more effective service promotion in cities and communalities.

Studies

Vol. 3, No.3, pp. 88-96

2020

Corresponding Author: Adedokun M. Funding: This study received no specific Ainancial support.

Received: 15 July 2020

Revised: 24 August 2020

Accepted: 14 September 2020

Published: 19 October 2020

(C) 2020 by the authors; licensee Academic

Publishing Group 
Ban Ki-Moon, United Nations Secretary-General (UNESCO, 2018) expressed strongly that education is a fundamental right and the basis for progress in every country. Parents need information about health and nutrition, if they are to give their children a good start in life. Prosperous countries of the world depend on skilled and educated workers and that education would conquer the challenges of poverty, combating climate change and achieving truly sustainable change and that education will compel countries of the world to work together. This implies that with investment in education, ,individual lives, national economy and our world would be transformed" (p.1).

Education being put to good use alters the lethargic attitudes of people towards sustainable development in every area of human life; it helps people to make informed judgment about the issues that concern their environment. Education, therefore, becomes a tool for accelerated progress towards the achievement of sustainable cities and communities. It makes peoplees voices in cities and communities to be heard; education helps individuals within the communities and cities to live healthy lives and aspire for meaningful creative and resilient lives as stated in SDG II.

Education 2030 (2018) Director-General of UNESCO stated that the benefits of education permeates all works of life right from the moment of birth and if poverty and hunger, is to be eradicated; if health is to be improved, if our planet is to be protected, there is need for education. If the world is to build more inclusive, resilient and peaceful societies, every individual must be empowered with access to quality lifelong learning. SDG 4 which is the sustainable development goal on education states that the type of education to embark upon should be one that ensures inclusive and equitable, quality education and one that promotes lifelong learning opportunities for all (INCHEON Declaration, p.3).

Education, therefore, is a lifelong process which involves both young and old and which leads to sustainability of not only cities and communities but of individuals within it. Education generates sustainable productivity through creativity and innovation brought about by technology.

\subsection{What Type of Education?}

This is an era of technological innovations and if communities and cities must thrive, they must be technologically driven. Business start-ups especially among young people in the cities and communities which is expected to make cities and communities thrive, may not yield the expected results if not adequately tied to technological innovations. Obsolete business-set up suffers patronage because everything being done now is tied to technological innovations. The first era of technology was marked by the use of water and steam for productivity. This less developed technological era was followed by a better technology that used electric power to bring about better productivity. This was followed by better technology in terms electronics and information technology; hence this passing age talks much about information and communication technology. This third era of technological advancement made dissemination of information easier through the use of social media of various types. With the information communication technology, business had been updated; transactions are now done virtually, demands and supplies are made on line and goods delivered to any part of the world while further requests or complaints on goods and services are made on line. This era of technology also saw the use of mobile phones by both the literates, the less literate and the illiterate members of the society to search for useful information for personal development as well as for the development of cities and communities.

The new innovation in terms of technology is referred to as Fourth Industrial Revolution. This technological revolution is hoped to fundamentally alter the way people live, work and relate to one another and the environment. If cities and communities would be sustained, it is important for communities and cities to embrace the fourth industrial revolution.

Klaus Schweb, the Founder and Executive Chairman of the World Economic Forum, states concerning the fourth industrial revolution; "we do not yet know how it will unfold but one thing is clear; the response to it must be integrated and comprehensive, involving all stakeholders of the global polity, from the public from and private sectors to academia and civil society" (n.p)

Achieving better progress and sustainability in cities and communities, every hand must be on deck to be immersed in this new industrial revolution with its high and better technological innovation. There is no doubt that the Fourth Industrial Revolution (41R), since it combines elements of earlier technological development would be a better technological revolution; one that would aid not only industrialization but development of persons in such a way that they would be able to use their initiatives to contribute to finding solutions to 
problems confronting cities and communities. Willingness to key into the new revolution is germane to the thriving of cities and community because it would aid better governance and this would have effect on leakages thus reducing corruption and its associated evils that have negative effects on development. The 4IR thus have the potentials for transforming every area of the world"s society with effective management in societies and one that is digitally driven.

The 4IR should be directed towards a future that reflects common societal values and objectives defining clearly how technology is affecting the lives of people. It's high time for people to come out of their traditional linear thinking and begin to think about moving out of comfort zones in cities and communities by creating disruptions so that innovative ideas will come in to shape the future of the world"s societies. Elements of dissatisfaction /disruption which needs technological solutions must be injected into communities so that people of cities and communities may care about the sustainability of their environment. An example is that of waste management in Nigeria Society. Wastes are dumped indiscriminately everywhere in the society. This has led to the idea of turning wastes into wealth. World Economic Forum (2019), states that 4IR is changing world"s cities "where the density and diversity of human settlement creates perpetually evolving ecosystems for ripe innovation" (n.p). Leaders must therefore be aware of disruptions taking place in their environment and be empowered to swing into action that would bring sustainability for now and long term benefit of citizens through various innovations in policies and sound decision making based on societal values so as to tackle existing problems paving way for good living for generations to come. World Economic Forum (2019), on "cities and the fourth industrial revolution" states that: "Fourth Industrial Revolution seeks to aid urban transformation through five pillars of consideration for city leaders. These are "demonstrating visionary leadership, building local innovation systems, embedding smart regulations, establishing public, private partnership and adopting global standards"(n.p). This implies that leaders in every society must be aware of changes caused by "dissatisfaction or disruption" and must be apt to adapt to such before communities and cities can be sustained. Leaders, therefore, have to be visionary, dynamic and innovative and ready to work with the dictates of technology without which there can be no sustainability of any form in cities and communities.

\subsection{Sustaining Cities and Communities}

Cities in Nigeria are majorly in shambles and therefore cannot be compared with the newly developed "smart cities" in developed world where everything is based on advanced technology. Smart cities are urban areas that use different types of electronic data censors to supply information that is used to manage assets and resources efficiently. Such includes data collected from citizens, devices and assets that is processed and analyzed to monitor and manage traffic transportation systems, power plants, water supply networks, waste management, law enforcement, information systems, schools, libraries hospitals and all other community services (McLaren \& Agyeman, 2015).

The former idea was that with ICT in full use, a smart city must be more responsive to challenges than one with a transactional relationship (Chan, 2017). It is therefore; clear that smart city concept is based on the integration of technologies and internet services for effective and efficient city operations and services. In such smart cities, technologies are put to full use, one can thus, allude to the idea of sustainability. Integrating the Fourth Industrial Revolution would make cities better and make emerging smart cities greater than what they used to be. With the aid of the 4IR, power of innovation and creativity would be put to use to seek solutions to problems emanating in cities and communities: The idea of the 4IR in creating cities and communities that are sustainable lies in empowering people to design and construct technology by themselves, localize such inventions to solve evolving local problems. Doing this, everyone in cities and communities is empowered not only to solve his own problem but those confronting cities and communities making such places better to live in and with sustainability efforts put in place, they are being prepared for future comfrontability. This idea of empowering people in cities and communities to make them sustainable is what Neil Gershenfeld called "giving people the tool" (Ratti, 2019).He is of the opinion that giving the people the tool is the solution to problems emanating in cities and by extension communities. He experimented this through his idea of "Fab-Lab" in Norway. Through "fab-lab", communities came together to solve identified problems and generate new ideas to help themselves and which involved the participation of all.

Studies

Vol. 3, No.3, pp. 88-96

2020

DOI: $10.53935 / 2641-533 x . v 3 i 3.144$

Corresponding Author: Adedokun M. O. Funding: This study received no specific

Article Hist

Received: 15 July 2020

Revised: 24 August 2020

Accepted: 14 September 2020

Published: 19 October 2020

(C) 2020 by the authors; licensee Academic

Publishing Group 
Because efforts at building sustainable city is empowering and participatory in nature, everyone should see him/herself as being able to solve every problem with the use of new innovations as being generated by 4IR.

Nigerian citizens and communities must be improved upon as cities are interspersed with slums thus, the so- called cities, look less of cities. Rural communities in Nigeria are deserted while urban slums increase and with the standard of living falling below expectation because majority of the migrants are either illiterate or not literate enough or lack skills with which they could be gainfully employed in cities. Though cities in Nigeria can be divided into two: the elitist area and the slum, the slums outweigh the elitists" and the result is that poverty ravages the so called urban cities. Out of school children as well as poverty ridden adults are seen roaming the streets begging for money. School children (after school hours) are seen hawking on the streets not minding the dangers inherent in it. All these are pointers to the fact that cities and communities need to be re -planned bearing in mind technological innovations so that future generations would not suffer these havocs.

Sustainable Development Goal 11(eleven) is about sustainable cities and communities with the aim of making cities and communities and other human settlements inclusive, safe, resilient and sustainable. (SDG11: Sustainable Cities and Communities). Many challenges are hindering efforts to sustain cities and communities one of which is that urban cities have been populated worldwide with half of the world ,s population living in urban areas and which by 2020 would increase by two third(2/3) (UNDP, 2018).

\subsection{Other Challenges Are}

- That cities which are supposed to be economic power houses and which are expected to be generating more than $80 \%$ of global GDP are full of myriads of problems such as poverty, hunger, housing shortages ,slum settlements and environmental degradations, air pollutions and dumping of wastes with its associated health hazards.

- That the challenge of climate change is more vivid in urban areas as almost $70 \%$ of greenhouse gas emissions come from cities. World Bank (2018). Such emissions cause serious air pollution which is very hazardous to life and urban planning which ought to lead to safe, resilient and sustainable cities. Business in cities remain ineffective with low productivity due to low transportation system. These challenges and more lead to joblessness, ill health and untimely death due to inability to access health services due to lack of funds and ignorance. All these pose great threat to sustainability of lives in cities and communities.

Sustaining cities and communities is more than taking care of environments as most people think. It is about being socially aware, being economically and politically aware. This awareness will culminate in wanting a positive change in the community and this is the gospel truth being preached by the fourth industrial revolution- disruption will lead to transformation in cities and communities.

Sustaining cities and communities is about seeking solutions to problems facing a group of people in their environment, making use of technological innovations interspersed with creativity to bring about sustainable change. Sustaining cities and communities include power utilization such as making use of sunlight , maintaining good agricultural practices for growing food to sustain good health for people, preserving biodiversity, restoring ruined ecologies ,managing wastes to generate wealth for the people and developing communities that could be sustained within nature"s limit (Akintayo, 2018).

Cities and communities would be sustained within the enclave of the fourth industrial revolution as it has the potential to raise global income levels and improve the quality of life for populations around the world as technology has made many things possible. New products are on the increase with effective services that increase the efficiency and pleasure of people se personal lives. The human dominated organism, that is, cities are the most dramatic manifestations of human activities. Yigitcanlar and Dizdaroglu (2015) submit that cities degrade human habitats, simplify specie composition, modify energy flow and cycling nutrients. In generic terms, sustainability is described as a normative concept that indicates the way human should act towards nature and the way they should and be responsible towards one another and future generations (Baumgärtner \& Quaas, 2010; Yigitcanlar \& Dizdaroglu, 2015).

Mayer (2015) perceives that the fundamental characteristic of sustainability is the idea of meeting the reasonable needs of the current generation while enhancing lives and ecosystems of future generations. Allan in YigitCanlar. and Kanzruzzaman (2015) describes sustainable development as the development that satisfies human needs and improves the quality of life in such a way that ecosystems should keep renewing. Elkingtn

\begin{tabular}{l} 
International Journal of Educational \\
Studies \\
Vol. 3 , No.3, pp. $88-96$ \\
2020 \\
DOI: $10.53935 / 2641-533 x . v 3 i 3.144$ \\
a Corresponding Author: Adedokun M. O. \\
Funding: This study received no specific \\
financial support. \\
Article History: \\
Received: 15 July 2020 \\
Revised: 24 August 2020 \\
Accepted: 14 September 2020 \\
Published: 19 October 2020 \\
C) 2020 by the authors; licensee Academic \\
Publishing Group \\
\hline | 92
\end{tabular}


(1997b) believes that in approaching sustainable development, one should consider environmental quality, economic property and social justice. All these cannot be achieved in the old traditional ways of doing things but by keying into the new technological advancement.

\subsection{Adult Education for Sustainability in the Era of the Fourth Industrial Revolution}

Technology is a strong tool for sustaining cities and communities. Traditional technology can be transformed to match the newly developed ones. People in small communities who are least educated and have no knowledge about modern technology should not be left out in this era of innovative technology. This is why government of nations especially developing nations should focus on adult education programmes, also industries or small enterprises should include short courses, trainings, re-training and on the job training in their establishment because technology needs collaboration and equity and it bridges the divide gap and accessibility gap. Criminalities pervades urban cities due to joblessness and those who are educated are found to be unemployable or under employed due to lack of technological skills that can make them creative and innovative and thus employable.

Luo, Liang, Wu, and Yang (2018) assert that in this era of knowledge economy, people pay more attention to lifelong education with the fast updating skill of knowledge and continuing emerging technologies. Adult education, therefore, is becoming an indicator of technological development and social progress. There is thus, a close relationship between the application of technology in adult education and innovation in doing things. Adult education is, therefore, of great importance in bringing solutions to identified problems in cities and communities. It is education of immediate relevance to societal growth. It is holistic in nature as it provides knowledge for both young and old because it is lifelong in nature. It is, therefore, an education of relevance in this era of sustainable development since sustainability is an age long and all life issue.

Adult education with its programmes has environmental outcomes; for people are made aware of keeping their environment safe, getting ready for disasters, locating their businesses in appropriate places ,taking good care of their health and homes and their vehicles to prevent gas emissions. Through programmes like community development and community education, awareness would be raised on diverse issues in communities that are detrimental to people se health, environment and occupations. Environmental adult education would enable people to make meanings out of their lives in cities and communities thus, transcending to peaceful and secured living.

Adult education for sustainability has to do with mentality hence, everyone needs to cultivate the habit of sustainable living because sustainability of cities and communities is about living which involves skills, knowledge, values, attitudes and behaviours. Adult education is about technology whether traditional or modern because the fourth industrial revolution and other technologies are predicated on existing traditional ideas. Technology can lead to creativity, new knowledge and skills which is termed innovation. With innovative ideas backed up by technology, life is made easier for people. As Mushi (1994) submits in his article on "Innovations in adult education", adult education can mean any form of learning beyond traditional schooling but which leads to personal fulfillment as a lifelong learner. People should, therefore, be made aware that learning is an ongoing process and this involves, making them learn about new technologies and applying them to their daily living

Adult education is therefore of great importance to sustainable living in cities and communities due to the following points:

- The learning activities vary to include a host of learning opportunities for equipping adults for greater opportunities in cities and communities. Its programmes include literacy, professional development education, citizenship education, extension services, health education, liberal education as well as retirement education. To boost people se opportunity for development through these programmes there is the need for interjecting these programmes with education in modern technology as this would boost their participations in community matters and making people $e^{e s}$ voices to be heard and thereby contributing to sustainable development in cities and communities and all over the world.

- Adult education is innovative in nature as it provides a lot of possibilities for realizing lifelong learning, reducing dependence on formal learning structures and encouraging individualized learning thereby, providing needed exposure into doings of relevance in the world around. This exposure through technological networking bring people into the world of creativity and awakening in people innovative tendencies. 
- It is education for personal fulfillment through innovations and it provides a forum for a safer, healthier, more prosperous and environmentally sound world ; helping individuals to contribute to social, economic, cultural progress, tolerance and international cooperation. It is the key to personal and social sustainability (Mauch \& Papen, 2018).

UNESCO (2018) sums up the role of adult education in sustainable development in the following way:

"innovation is needed in adult learning and adult education in that there are nearly one billion illiterate adults worldwide and about the hundreds of millions of unemployed people and workers suffering from appalling working conditions and the masses of women excluded from equal participation in many domains who also belong to this human kind... there are also damages done to environment, a continuing crises in the field of nutrition and population development and continuing crises in the field of health..." (p.13).

The solution lies in adult education and its many programmes to bring about change in knowledge and competence through innovative technology as it is being propounded by the fourth industrial revolution. Technological innovations in adult and non-formal education is therefore, a must as it calls for doing things in different and better ways because it implies addressing problems that could not be solved by traditional means.

\section{The Fourth Industrial Revolution and Technological Innovations}

Technology affects the way people act and to Thompson (2011) technology is more than tools and machines. He sees technology as the answer to all social, economic political and medical ills. in Thompson (2011) states that technology is used to refer to tools, instruments, machines, organizations, media, methods, techniques and systems. This implies that technology is an inclusive term that affects every aspect of human living in cities and communities and that the digital divide that separates the "haves and the have- nots" must be bridged, so also the gaps between those who have a blend of cognitive and technical capabilities and those who do not have must be bridged. This becomes important as the technological, social and economic effects of the fourth industrial revolution are changing the world and so none must be left out. According to World Economic Forum (2019) its effect is "more evident in the world"s cities where the density and diversity of human settlement creates evolving ecosystems for ripe innovations" (n.p). Everyone in cities and communities must be made aware of changes around them and be empowered to bring in transformations for sustainable living. This is based on the fact that technology brings creativity and innovations. Innovation to Ayeni and Olanipekun (2015) is the creation of something new or developing a new idea. This involves introduction of a new method of production especially with the use of appropriate method. A good innovator, therefore, is that person who puts new knowledge into practical use to bring better living standard to himself and to improve his community and taking bold steps to access new ideas not only for now but in preparation for future generations. Technological innovations are evolving and changing daily because they are vital to lives and living. Technological innovation is thus, an integral part of human experience and one that stresses the importance of individuals as sources of innovation. Hekkert, Suurs, Negro, Kuhlmann, and Smits (2007).

Examples of technological innovations are smart phones which enable people whether literate, semi literate or illiterate to improve on their businesses, making important contacts and gathering relevant information to stay in tune in their endeavours and preventing them from being moribund. These technological devices are being passed down to younger generations in a better and smarter forms thus, enabling sustainable development. The fourth industrial revolution is based on this fact because it represents an improvement on the earlier technologies. Various technological innovations have thus led to:

- Improvement in science which has led to researches being carried out on how to enhance living in terms of improved health, business management, re-organization of cities and communities and public participation in all areas of living in an easier way.

International Journal of Educational Studies

Vol. 3, No.3, pp. 88-96

2020

DOI: $10.53935 / 2641-533 x . v 3 i 3.144$

Corresponding Author: Adedokun M. O. Funding: This study received no specific financial support.

Article History:

Received: 15 July 2020

Revised: 24 August 2020

Accepted: 14 September 2020

Accepted: 14 September 2020

(C) 2020 by the authors; licensee Academic

Publishing Group
- Better interaction on a global basis especially with the use of smart phones and through social media

- Production of new items and new ways of doing things

- Constant positive change in cities and communities.

Making good use of fourth industrial revolution would mean

- harnessing the power of technology to seek solution to problems emanating in cities and communities

- Helping people to design and construct technology that would be of use in their local environments to solve their identified local problems by empowering them technologically

- Empowering leaders to be more visionary by making innovative policies that have long term benefits 
for citizens

- Giving people unlimited access to processing power, storage capacity and gaining insights into new knowledge, skills and values that would boost personal as well as community sustainability.

At the core of the fourth industrial revolution is technological empowerment. When people are empowered, they stand the chance to change their world. This is what Neil Gershenfeld calls giving the people the

„tool".(weforum.org) With his idea of „Fab-Lab" in Norway, communities came together to solve identified problems and they generated new ideas to help themselves out of their problems. Participation of community members and leaders is therefore, core to the fourth industrial revolution for it to bring about sustainability of persons, businesses, governance, cities and communities.

It is of importance to note that old technologies form the basis for the new industrial revolution and this signifies improvement. This implies that old ideas mixed with modern ones in cities and communities will result in creativity and innovations and the end result will be sustainable development. The availability, awareness and education on the fourth industrial revolution is germane in order to allow technologically disadvantaged cities, communities and people greater opportunity and equity of access to high standard of living which is the essence of sustainability.

\section{Conclusion}

The authors examined the impact of the fourth industrial technological revolution on the role of adult education in sustaining cities and communities in Nigeria. Documents and authors were reviewed on adult education, sustainable development, technology and fourth industrial revolution. The paper highlighted that adult education with technological innovations have the capacity of making a positive difference in the lives of both young and old in cities and communities to the extent that cities and communities would be remolded and there would be improvement in the outlook of cities and communities and living standards would be raised. The fourth industrial revolution which is a blend of earlier technologies has the capacity of empowering every community member to the level of sustainability.

\section{Recommendations}

Based on the above, the following are recommended;

- Challenges facing adult populace in the face of technological innovations such as illiteracy which hinders the use of technological tools, lack of exposure to technological tools ,fear of the use of the tools and lack of digital literacy should be removed by appropriate strategies in the fourth industrial revolution

- Adult learning should include technology classes into its curriculum because it will lead to people being creative and innovative to solve problems facing their cities and communities in modern and appropriate ways

- Learning in all its forms should be sustained to lead to an all round sustainable development as sustainable development is not a one-time activity but a lifelong one.

- E-learning should be introduced into programmes of adult education to foster e-services in all its ramifications and this is contingent on making education available and accessible to all.

- Government should embellish their governance with sound and innovative policies and decision making so that communities and cities would be the best they could be.

- Leaders should be visionary, building local innovative systems into their leadership and they should be democratic in leadership so as to enhance participatory sustainability

- People should be enlightened through programmes of adult education as to what constitutes sustainability and the roles they should play

- The tenets of the fourth industrial revolution should be made known to all.

\section{References}

Akintayo, E. T. (2018). Sustainable development. In Keynote address at the Faculty of Education, National Conference 2018; Theme: Emerging global trends in education for sustainable development. May 22-25, 2018. Ado-Ekiti: Ekiti State University.

Ayeni, R. K., \& Olanipekun, D. B. (2015). Theories of entrepreneurship development. In A. A., Awe, R.K. Ayeni, and S. Ogunsanya (Eds.), Introduction to entrepreneurship. Ado-Ekiti: Greenline Publishers.

Baumgärtner, S., \& Quaas, M. (2010). What is sustainability economics? Ecological Economics, 69(3), 445-450. 
Chan, K. (2017). What is a smart city, expatiate lifestyle. Retrieved from: http://Wikipedia.org.

Education 2030. (2018). INCHEON Declaration towards inclusive and equitable quality education and life learning for all. Retrieved from: www.right-to-education.org/titlesresources-attachment/education-2030-incheon- declaration-andframework-foraction2015-en.

Elkingtn, J. (1997b). Carnibals with forks: The triple bottom line of the 21 Century business Oxford. UK: Capstone Publishing.

Global Goals. (2018). Goal 1: No poverty. Retrieved from: www.globalgoals.org/global-global-goals-sustainable- development.

Hekkert, M. P., Suurs, R. A., Negro, S. O., Kuhlmann, S., \& Smits, R. E. (2007). Functions of innovation systems: A new approach for analysing technological change. Technological Forecasting and Social Change, 74(4), 413-432.

Luo, L., Liang, Z., Wu, G., \& Yang, X. (2018). Modem education technology with creativity of continuing education. Retrieved from: https://smartech.gatech.edu/bitstream/handle/1853/24421/162.pdf.

Mauch, W., \& Papen, U. (2018). Making a difference; innovations in adult education. Retrieved from: http://hunesco.org/images/0011/001102/II024/20.pdf

Mayer, A. L. (2015). Strengths and weaknesses of common sustainability indices for multidimensional systems. Environment International, 34(2), 277-291.

McLaren, D., \& Agyeman, J. (2015). Sharing cities: A case study for truly smart and sustainable cities: MIT Press in Smart City.

Mushi, P. A. (1994). Innovations in adult education: The changing perspective of the post-literacy curriculum in Tanzania. International Review of Education, 40(2), 173-177.

Ratti, C. (2019). Cities and fourth industrial revolution. Retrieved from: https://www.devtschland-und-dve-welt-2030.de

Thompson, M. (2011). Adult education in a technological society. PAACE Journal of Lifelong Learning, 20, 51-71.

UNDP. (2018). Goal II: Sustainable cities and communities. Retrieved from: http://www.undp.org./content/undp/en/home/mdgoverview/post-2015-development-agenda/goals-11.html.

UNESCO. (2018). Sustainable development begins with education. Retrieved from: http://unesco.org/images/0023/002305320508e.pdf.

UNESCO. (2019). SDG resources for educators-sustainable cities and communities. Retrieved from: https://en.unesco.org/themes/education/sdgs/material/II.

UNICEF Publications. (2017). Unicef annual Report. Retrieved from: https://www.unicef.org/index 102899.html.

World Bank. (2018). Urban development overview. Retrieved from: http://www.worldbnk.org/en/topic/urbandevelopment/overview.

World Economic Forum. (2019). Cities and the fourth industrial revolution. Retrieved from: https://www.weforum.org/projects/citiesand-the-fourth-industrial-revolution.

Yigitcanlar, T., \& Dizdaroglu, D. (2015). Ecological approaches in planning for sustainable cities: A review of the literature. Global Journal of Environmental Science Management, 1(2), 71-94.

YigitCanlar., T., \& Kanzruzzaman, M. D. (2015). Planning, development and management of sustainable cities: A commentary from the guest editors. Journal of Sustainability, 7(11), 14677-14688

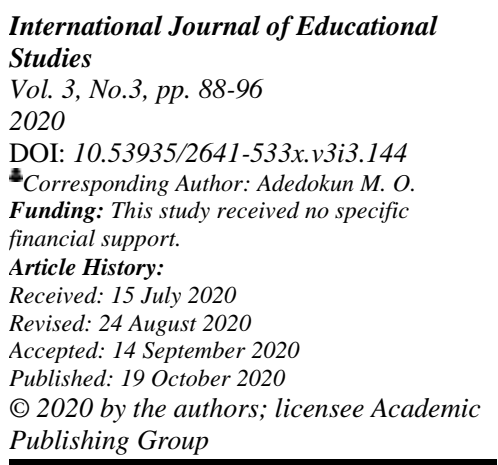

